\title{
Accuracy of High-Field Intraoperative MRI in the Detectability of Residual Tumor in Glioma Grade IV Resections
}

\section{Treffsicherheit der Intraoperativen MR-Bildgebung (ioMRI)in der Nachweisbarkeit von Resttumorgewebe zur Resektion hochgradiger (Grad IV) Gliome}

Authors

Volker Heßelmann ${ }^{1}$, Ann-Kathrin Mager ${ }^{1}$, Claudia Goetz $^{2}$, Oliver Detsch ${ }^{3}$, Hannah-Katharina Theisgen ${ }^{4}$, Michael Friese $^{5}$, Wolfram Schwindt ${ }^{6}$, Joachim Gottschalk ${ }^{5}$, Paul Kremer ${ }^{2}$

Affiliations

1 Radiology/Neurologie, Asklepios-Klinik Hamburg-Nord, Hamburg, Germany

2 Department of Neurosurgery, Asklepios Klinik Nord, Hamburg, Germany

3 Department of Anaesthesiology and Intensive Care Medicine, Asklepios Klinik Nord, Hamburg, Germany

4 Department of Neurosurgery, Universitatsklinikum Schleswig-Holstein Campus Kiel, Germany

5 Department of Pathology and Neuropahthology, Asklepios Klinik Nord, Hamburg, Germany

6 Department of Clinical Radiology, University Hospital Münster, Münster, Germany

Key words

intraoperative, treatment planning, gadolinium, aminolaevolinic acid, mr imaging, high-grade glioma

received 17.10.2016

accepted 01.03.2017

Bibliography

DOI http://dx.doi.org/10.1055/s-0043-106189

Published online: 2017 | Fortschr Röntgenstr 2017; 189:

519-526 @ Georg Thieme Verlag KG Stuttgart · New York ISSN 1438-9029

Correspondence

Dr. Volker Heßelmann

Radiology/Neurologie, Asklepios-Klinik Hamburg-Nord

Tangstedter Landstraße 400

22417 Hamburg

Germany

Tel.: ++ 40/18 18/873332

Fax: $++40 / 1818 / 873688$

v.hesselmann@asklepios.com

\section{ZUSAMMENFASSUNG}

Einleitung Ziel der Studie ist die Untersuchung der Sensitivität und Spezifität der intraoperativen MRT (ioMRI) zum Nachweis von Resttumorgewebe auf der Basis der T1-Wichtung nach GD-DPTA im Vergleich zur Histopathologie (Goldstandard) bei neurochirurgischen Operationen von WHO Grad IV Gliomen.

Material und Methoden 68 Patienten (Durchschnittsalter 59 Jahre, 26 weiblich, 42 männlich mit primären oder rezidivierenden WHO Grad IV Gliomen erhielten gleichzeitig eine floureszenz-, eine neuronavigations- und ein ioMRI-gestützte Resektion. Bei Nachweis von KM-Anreicherungen in T1-Wichtung in der ioMRI erfolgte eine Nachresektion, deren histopathologischen Proben (Goldstandard) von einem Neuropathologen bewertet wurde. Nach kompletter Entfernung des flouresziierenden oder MR-tomografisch nachweisbaren Resttumorgewebes wurde die OP beendet. Zusätzlich wurde die postoperative MRT zum Nachweis residueller KM-Anreicherungen mit der ioMRI verglichen und als in die Auswertung mit einbezogen.

Ergebnisse Bei 43 Patienten wurde in der ioMRI Resttumorgewebe nachgewiesen und histopathologisch bestätigt. In 16 Fällen war die zweite ioMRI ohne histopathologischen Nachweis von Resttumor richtig negativ (4 Rezidive, 12 Primärtumore). In 7 Fällen (3 Rezidive, 4 Primärtumore) war der ioMRT Befund falsch positiv, in zwei Patienten (1 Rezidiv, 1 Primärtumor) falsch negativ. Für alle Patienten betrug die Sensitivität $95 \%$, die Spezifität $69,5 \%$, für die Rezidive $94 \%$ und $57 \%$ und für die Primärtumore $96 \%$ und $75 \%$. Der positive Vorhersagewert war $86 \%$, der negative Vorhersagewert $88 \%$ für alle Patienten, $84 \%$ und $80 \%$ für die Rezidive und 87 und $92 \%$ für die Primärtumore.

Schlussfolgerung Die ioMRI ist sensitiv im Nachweis von kontrastmittelanreicherndem Resttumorgewebes nach Gliomresektion. Narbengewebe und Kontrastmittelleckagen durch Blutaustritt führen zu Fehlinterpretationen und reduzieren die Spezifität. 


\section{Kernaussagen}

- Die ioMRI ist hochsensitiv im Nachweis residueller, kontrastmittelanreichender Resttumoranteile in der Gliomresektion

- Artefakte durch blutungsbedingte Kontrastmittelaustritte und reaktive Kontrastmittelanreicherungen durch Narbengewebe limitieren die Spezifität der ioMRI

- Eine suffiziente Blutungsstillung ist entscheidend für eine hohe Aussagekraft der ioMRI

\section{ABSTRACT}

Objective To assess the sensitivity/specificity of tumor detection by $\mathrm{T} 1$ contrast enhancement in intraoperative MRI (ioMRI) in comparison to histopathological assessment as the gold standard in patients receiving surgical resection of grade IV glioblastoma.

Materials and Methods 68 patients with a primary or a recurrent glioblastoma scheduled for surgery including fluorescence guidance and neuronavigation were included (mean age: 59 years, 26 female, 42 male patients). The ioMRI after the first resection included transverse FLAIR, DWI, T2-FFE and T1-3d FFE +/- GD-DPTA. The second resection was performed whenever residual contrast-enhancing tissue was detected on ioMRI. Resected tissue samples were histopathologically evaluated (gold standard). Additionally, we evaluated the early postoperative MRI scan acquired within $48 \mathrm{~h}$ post-OP for remaining enhancing tissue and compared them with the ioMRI scan.

Results In 43 patients ioMRI indicated residual tumorous tissue, which could be confirmed in the histological specimens of the second resection. In 16 (4 with recurrent, 12 with pri- mary glioblastoma) cases, ioMRI revealed truly negative results without residual tumor and follow-up MRI confirmed complete resection. In 7 cases ( 3 with recurrent, 4 with primary glioblastoma) ioMRI revealed a suspicious result without tumorous tissue in the histopathological workup. In 2 ( 1 for each group) patients, residual tumorous tissue was detected in spite of negative ioMRI. IoMRI had a sensitivity of $95 \%$ (94\% recurrent and $96 \%$ for primary glioblastoma) and a specificity of $69.5 \%$ ( $57 \%$ and $75 \%$, respectively). The positive predictive value was $86 \%$ ( $84 \%$ for recurrent and $87 \%$ for primary glioblastoma), and the negative predictive value was $88 \%$ ( $80 \%$ and $92 \%$, respectively).

Conclusion ioMRI is effective for detecting remaining tumorous tissue after glioma resection. However, scars and leakage of contrast agent can be misleading and limit specificity.

\section{Key points}

- Intraoperative MRI (ioMRI) presents with a high sensitivity for residual contrast-enhancing tumorous tissue during glioma resection.

- Contrast leakage due to bleeding and scars with reactive contrast enhancement can cause possible misleading artifacts in ioMRI, leading to a limited specificity of ioMRI.

- Bleeding control in glioma resection is crucial for successful usage of ioMRO for glioma resection.

\section{Citation Format}

- Heßelmann V, Mager A, Goetz C et al. Accuracy of HighField Intraoperative MRI in the Detectability of Residual Tumor in Glioma Grade IV Resections. Fortschr Röntgenstr 2017; 189: 519-526

\section{Introduction}

Evolution of imaging technologies and procedural techniques like operation microscope, intraoperative ultrasound, neuronavigation, fluorescence-guided resection, and intraoperative MRI continuously improved the surgical resection of high-grade gliomas. Improved resection grade of contrast-enhancing tissue [1 - 7] prolongs the patient survival rate and preserves eloquent brain function and life quality [ $1-9]$. Studies dealing with the accuracy of fluorescence-guided resection detected a sensitivity of about $90 \%$ and a negative predictive value of $76-91 \%[1,10,11]$. However a negative predictive value of 0.26 in the study of Roberts et al. also showed that there are deficits in fluorescence-guided resection with respect to the detection of residual tumorous tissue in normal appearing resection borders [11] so that there is a need for additional intraoperative resection control. Intraoperative CT and MRI have been integrated since the last decade into the operating room [12]. Starting with low-field systems between 0.02 0.5 Tesla [13] and open MRI scanners [14], high-field systems were introduced starting in 2000 [15]. In a controlled randomized study with a low-field system, Senft et al. [16] detected $96 \%$ gross tumor resection in the patient group who were investigated by
ioMRI, versus $68 \%$ gross total resection in the control group. Combining the concept of fluorescence-guided tissue resection and ioMRI, Coburger et al. found a higher extent of resection with fluorescence-guided resection and ioMRI (100\%) in comparison to ioMRI alone (82\%) [2]. Gessler et al. found that ioMRI und fluorescence guidance were inconsistent in $47 \%$ of patients being resected under surveillance with ioMRI in the first line and fluorescence-guided resection after ALA administration in the second line [17]. A direct comparison between the sensitivity and specificity of linear intraoperative ultrasound and intraoperative MRI was provided by Coburger et al. [18], who found a sensitivity of $76 \%$ for linear intraoperative ultrasound and $55 \%$ for intraoperative MRI. The specificity was $58 \%$ for linear ultrasound and $74 \%$ for intraoperative MRI [18]. Linag and Shoulder stated in their review that ioMRI is a useful tool in conjunction with other techniques like neuronavigation with fMRI and DTI-based planning and fluorescence-guided resection [19], but others continue to criticize the still insufficient number of controlled prospective studies and regard fluorescence-guided resection of high-grade gliomas as equal according to the extent of tumor resection [12]. A recent randomized controlled study of these authors including a rather 
small sample size of 14 showed no benefit of ultra-low-field ioMRI compared to standard resection therapy [20].

The aim of this study was to define the rate of true positive detection of residual tumor by $\mathrm{T} 1$ contrast enhancement in intraoperative MRI on the basis of sensitivity/specificity assessment and histological specimens received by repeated post-ioMRI resection of suspected tissue and to describe the imaging appearance of false-positive MRI lesions to help assess the validity of this new method in glioma resection control.

\section{Materials and Methods}

\section{Patients}

All 68 of 220 patients with a grade IV glioma diagnosed by MRI and receiving an ioMRI and 5ALA guide resection of primary and recurrent glioblastoma from July 2011 to February were prospectively collected and included in this investigation (mean age: 59 years, 26 female, 42 male patients) in a consecutive manner. Data were prospectively and retrospectively assessed for scientific investigation. Eligibility criteria for patient selection were defined as follows according to the STARD criteria. Inclusion criteria were: patients with newly diagnosed or recurrent glioblastoma between 18 und 75 years, a preoperative MRI scan with a contrast-enhancing tumor and additional intraoperative fluorescence-guided resection and written informed consent to the application of 5ALA and intraoperative MRI. Written informed consent was obtained prior to the operation procedure and the scientific evaluation of data. The exclusion criteria were: radiation therapy 6 months before surgery or resurgery, security concerns or contraindication for ioMRI or preexisting neurological disease or deterioration.

\section{Technique}

For intraoperative MRI we used a 1.5 Tesla MRI scanner (Philips Achieva 1.5 T, Philips Best, The Netherlands) which is integrated into the neurosurgical operating room but is separated by an automatic door when not in use so that it is accessible for outpatient procedures.

The bottom part of the coil is placed under the head prior to operation. After complete sterile draping, the upper part of the coil is positioned on top of the patient and connected to the lower part and to the scanner (Heidberg Coil system, NORAS, Höchberg, Germany). After positioning of the patient in the scanner and acquisition of a scout, the following scans were performed: FLAIR tra (TR $6000 \mathrm{~ms}$, TI $2000 \mathrm{~ms}$, TE $120 \mathrm{~ms}$, slice thickness $6 \mathrm{~mm}$ ), T1 SE sag (TR $510 \mathrm{~ms}$, TE $10 \mathrm{~ms}$, slice thickness $5 \mathrm{~mm}$ ) and T1 - 3 D FFE (TR $10.1 \mathrm{~ms}$, TE $4.6 \mathrm{~ms}$, slice thickness $1 \mathrm{~mm}$ ) before and after GD contrast administration, T1-SE sag (TR $539 \mathrm{~ms}$, TE $10 \mathrm{~ms}$ ), T2-FFE (TR $896 \mathrm{~ms}$, TE $23 \mathrm{~ms}$ ), DWI tra, ADC tra. Contrast administration was applied immediately before T1-weighted imaging to avoid leakage. Air artifacts are reduced by the operative resection defect with a solution containing Refobacin.

All surgeries were performed with an operation microscope. After fixation of the skull in the NORAS fixation and coil system and sterile draping, trepanation was performed and tumorous tissue was removed under white light condition and fluorescence- guided control as completely as possible. Specimens of tumor and tumor margins in all directions were collected and primarily investigated. Gross total resection or most complete resection was achieved and no active bleeding was visible. The resection area was treated with a gentamycin solution (holy water). The trepanation was then covered with a sterile drape to prepare the patient for ioMRI.

Using MRI-visible markers for the T1-FFE KM sequence, reorientation and coregistration with the preoperative MRI data were performed. A senior radiologist and a technician acquired and interpreted the images immediately, marked the assumed contrast-enhancing residual tumor in the PACS system and discussed with the neurosurgeon by phone or met the neurosurgeon directly to decide in consensus whether additional resection should be performed. Whenever suspected residual tumor was detected, the patient was moved back into the OR and the tissue in question was removed after coregistering the ioMRI data in the neuronavigation system.

All specimens were identified, marked and examined by a neuropathologist. For intraoperative evaluation, a fast evaluation with hematoxylin eosin staining was performed to help decide whether further resection should be performed. The final histopathological workup consisted of hematoxylin eosin (HE) staining, a period acid shift stain (PAS), a Van Gieson's stain (EvG) and an immunohistochemical workup with GFAP, IDH-1 und MiB-1 antibody staining (Dako-Autostainer). In particular cases, CD 163, Protein S-100, CD 31, p53, neurofilament antibodies and epithelial membrane antigen (EMA) stains were prepared.

After 24-48 hours, an early postoperative MRI scan was acquired, including FLAIR imaging (TR $6000 \mathrm{~ms}$, TI $2000 \mathrm{~ms}$, TE $120 \mathrm{~ms}$ ), T2-weighted (TR $3000 \mathrm{~ms}$, TE $100 \mathrm{~ms}$, slice thickness $2.5 \mathrm{~mm}$ ) imaging in three imaging directions, T1-weighed spin echo imaging (TR $510 \mathrm{~ms}$, TE $10 \mathrm{~ms}$, slice thickness $5 \mathrm{~mm}$ ) und T1-weighted 3D imaging (T1 - 3 D FFE (TR $10.1 \mathrm{~ms}$, TE $4.6 \mathrm{~ms}$, slice thickness $1 \mathrm{~mm}$ ) before and after administration of $\mathrm{Gd}$ DPTA with a dosage of $0.2 \mathrm{mg} / \mathrm{kg}$ b.w.

Tissue was regarded as suspicious for tumorous rest if there was a defined area of contrast enhancement close to the resection margin or area of contrast enhancement in areas distant from the resection.

The reports, documentation of the detection of residual tumor and the documented PACS information were used as the radiological definition of residual tumor. It was correlated with the final neuropathological report that was regarded as the gold standard. All false-positive MRI cases were reevaluated, and the histopathological diagnoses were collected and described in the results section.

Data were investigated for sensitivity, specificity, positive and negative predictive value for all patients, primary and recurrent glioblastomas. Statistical workup of patient characteristics, imaging and histopathological results were evaluated using the PSPP software package (www.gnu/.org/software/pspp) (॰ Fig. 1). 
glioma resection, neuronavigation, flourescence guidance,

glioblastoma in histopathological staining

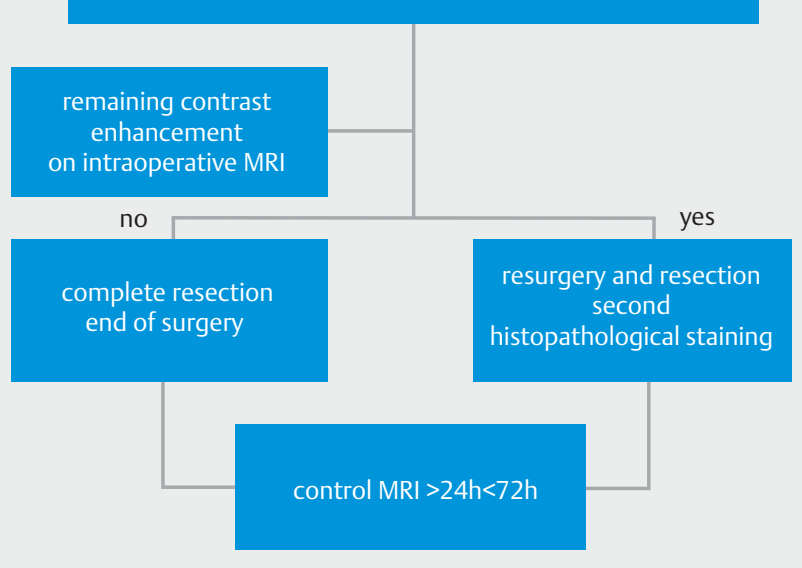

- Fig. 1 Workflow of glioma resection with fluorescence guidance and intraoperative MRI control. After complete resection under fluorescence guidance, intraoperative MRI was performed as immediate resection control. If residual contrast enhancement was seen on ioMRI, the resection area was reevaluated, and the suspected tissue was resected. For all specimens histopathological workup was performed.

- Abb. 1 Flussdiagramm für eine Gliomresektion unter Floureszenzsteuerung und intraoperativer MRT-Kontrolle. Die ioMRI wird unmittelbar nach der ersten Resektion durchgeführt. Bei residueller Kontrastmittelanreicherung in der ioMRI wird die Resektionshöhle erneut inspiziert und mögliches Resttumorgewebe entfernt. Alle Gewebsproben der Nachresektion werden histopathologisch aufgearbeitet.

\section{Results}

68 patients with grade IV glioma were included in this investigation, as they received intraoperative MRI and immediate postoperative MRI and data were completed for further evaluation ( Table 1). 45 patients presented with primary glioblastoma, and 23 patients presented with recurrent glioblastoma. Patient characteristics are summarized in - Table 1. 43 of these 45 patients with residual tumor tissue being detected in the specimens of the repeated resection were counted with a true-positive ioMRI evaluation. In 16 cases ioMRI revealed truly negative results without enhancing residual tumor and enhancing tissue in postoperative follow-up MRI, 4 in the recurrent glioblastoma group and 12 in the primary glioblastoma group. A second resection was not performed in these cases. Postoperative control MRI confirmed complete removal of contrast-enhancing tissue in these cases. In 7 cases ( 3 with recurrent, 4 with primary glioblastoma), ioMRI revealed a suspicious result without tumorous tissue in the histopathological workup, so that they were regarded as false-positive results of ioMRI. In two (1 for each group) patients, residual tumorous tissue was found in spite of negative ioMRI as defined by the radiologist, after repeated resection initiated by the neurosurgeon due to suspicious intraoperative aspects of resection margins that were not concordant with the ioMRI appearance. In the
- Table 1 Patient characteristics for all included patients including age, sex, Karnofsky-Index, therapeutic strategies, tumor localization and resection rate.

Tab. 1 Klinische und therapeutische Details der eingeschlossenen Patienten mit Angaben zum durchschnittlichen Alter, Geschlecht, Karnofsky-Index, therapeutische Strategien, Tumorlokalisation und Resektionsrate.

\begin{tabular}{|c|c|c|}
\hline characteristics & n (range) & $\%$ (range) \\
\hline mean age & 59 & 10.14 \\
\hline \multicolumn{3}{|l|}{ sex } \\
\hline female & 26 & 38 \\
\hline male & 42 & 62 \\
\hline mean Karnofski Index & $81.3(18.58)$ & \\
\hline \multicolumn{3}{|c|}{ main region occupied by tumor } \\
\hline frontal & 20 & 29.4 \\
\hline occipital & 7 & 10.3 \\
\hline parietal & 7 & 10.3 \\
\hline temporal & 31 & 45.6 \\
\hline central & 3 & 4.4 \\
\hline \multicolumn{3}{|l|}{ adjuvante therapie } \\
\hline temozolomide & 61 & 89.7 \\
\hline other (PVC, etc.) & 5 & 7.4 \\
\hline no therapy & 2 & 2.9 \\
\hline \multicolumn{3}{|l|}{ radiation therapy } \\
\hline yes & 64 & 94.1 \\
\hline no & 4 & 5.9 \\
\hline \multicolumn{3}{|c|}{ gross total resection rate } \\
\hline yes & 57 & 83.8 \\
\hline no & 11 & 16.2 \\
\hline
\end{tabular}

false-positive cases, MRI was reevaluated for the appearance of contrast-enhancing tissue. In 4 cases the contrast enhancement showed a rather weak appearance, and in 2 cases a signal increase on the T1-weighed native scan was detected. In one case T2weighted suspected residual tumorous tissue was diagnosed in addition to residual contrast enhancement, but no residual tumorous tissue was found.

The sensitivity was $95 \%$, the specificity was $69.5 \%$, the positive predictive value was $86 \%$ and the negative predictive value was $88 \%$ for the whole group. For the recurrent glioblastoma group the values were $94 \%, 57 \%$ and $84 \%$ and $80 \%$, respectively. For the primary glioblastoma group the values were was $96 \%$ and $75 \%$ for sensitivity and specificity and $87 \%$ and $92 \%$ for the positive and negative predictive value, respectively ( $\triangleright$ Table 2 , - Fig. 2, 3).

\section{Discussion}

Optimization of the resection rate of diseased tissue in glioblastoma is crucial for patient survival [21]. Patients with almost com- 
- Table 2 The sensitivity for all tumors was calculated as $95 \%$ and the specificity as $69.5 \%$. The negative predictive value was $88 \%$, and the positive predictive value was $86 \%$. For recurrent glioblastoma the sensitivity was $94 \%$, the specificity was $57 \%$, the negative predictive value was $88 \%$ and the positive predictive value was $84 \%$. For primary glioblastoma the sensitivity was $96 \%$, the specificity was $75 \%$, the positive predictive value was $87 \%$ and the negative predictive value was $92 \%$. Showing equal sensitivity ioMRI appears more specific in primary than in recurrent glioblastoma.

- Tab.2 Tabellarische Darstellung der ioMRI-Diagnosen nach der ersten Resektion und der histopathologischen Befunde der Gewebsproben. Die Sensitivität konnte mit $95 \%$ bestimmt werden und die Spezifität mit $86 \%$. Für Rezidivglioblastome beträgt die Sensitivität $94 \%$, die Spezifität $57 \%$, der negative Vorhersagewert $88 \%$ und der positive Vorhersagewert 84\%. Für primäre Glioblastome betrug die Sensitivität $96 \%$, die Spezifität $75 \%$, der positive Vorhersagewert $87 \%$ und der negative Vorhersagewert $92 \%$. Bei gleicher Sensitivität erscheint die ioMRI bei primären Glioblastoma spezifischer für Resttumorgewebe.

\begin{tabular}{|c|c|c|c|c|c|c|}
\hline & no rest (MRI) n & rest (MRI) n & sensitivity \% & specificity $\%$ & PPV\% & NPV\% \\
\hline all tumors & & & 95 & 69.5 & 86 & 88 \\
\hline no remaining tumor (histology) $n$ & 16 & 7 & & & & \\
\hline remaining tumor (histology) $n$ & 2 & 43 & & & & \\
\hline recurrent glioblastoma $(n=24)$ & & & 94 & 57 & 84 & 80 \\
\hline no remaining tumor (histology) $n$ & 4 & 3 & & & & \\
\hline remaining tumor (histology) n & 1 & 16 & & & & \\
\hline primary glioblastoma $(n=44)$ & & & 96 & 75 & 87 & 92 \\
\hline no remaining tumor (histology) n & 12 & 4 & & & & \\
\hline remaining tumor (histology) n & 1 & 27 & & & & \\
\hline
\end{tabular}

plete resection of diseased tissue showed a better overall survival rate $[8,22]$. As Albert et al. showed already in 1994, the extent of tumor resection influences the survival rate of glioblastoma resection [23]. However, the rate of complete resection at that time point was only $20 \%$ using neuronavigation and white light microscope technology. A crucial improvement in glioma resection technique was achieved with fluorescence-guided glioma resection [8]. Since this decade, intraoperative MRI has become an additional technical procedure for intraoperative resection control in glioma surgery $[2,15,16]$. Eyüpoglu et al. used high-field (1.5T) ioMRI and ALA-guided resection and could show that the extent of resection increases from $84 \%$ to $99 \%$ with the additional usage of ioMRI. The combination with 5-ALA-guided resection was also advantageous in the vicinity of eloquent brain regions, facilitating more radical resection compared to 5-ALA alone [5].

Showing $97 \%$ resectability of contrast-enhancing tissue after intraoperative MRI [24], high-field ioMRI in our study showed a sensitivity of $95 \%$ but a rather low specificity of $69.5 \%$, which was related to scars, bleeding, artifacts and a personal factor of a higher affinity to decide for a second resection if contrast enhancement was seen, to avoid misinterpretations leading to remaining contrast-enhancing tumorous tissue. After dividing glioblastomas into subgroups of recurrent and primary glioblastomas, the specificity was markedly reduced to $57 \%$ in the recurrence glioblastoma group, showing the role of reactive changes in misinterpreting ioMRI.

The sensitivity in our evaluation exceeds the sensitivity of $55 \%$ in the study of Coburger et al. [18], while their specificity of $74 \%$ is comparable with our findings. They stated that the accuracy of ioMRI might be underestimated due to this limitation, and that ioMRI shows an underdetection of solid tumor masses. This goes along with the findings of Eyüpoglu and Gessler [5, 17], who both revealed inconsistent findings between ioMRI and fluorescence guidance. Gessler described that ioMRI was the only indicator for residual tumor in only $26.3 \%$ of cases and fluorescence guidance in $21.1 \%$ of cases. Gessler et al. agree with Eyüpoglu that 5-ALA may by misleading if tumorous tissue is hidden by healthy tissue, spatula or blood [25], and complementary use of ioMRI may help to avoid these pitfalls [5]. In this study the sensitivity was $75 \%$ and the specificity was $100 \%$ for ioMRI, while the sensitivity was $70 \%$ and the specificity was $100 \%$ for fluorescence guidance. As in our study, Knauth et al. found cases with inconclusive MRI findings (9.7\%). As stated by the authors, uncertain MRI findings were mainly surgery-induced (electrocoagulation, tissue ablation) and were not residual tumor.

In summary, complementary use of fluorescence guidance, intraoperative ultrasound and/or ioMRI may optimize resection rates and can be regarded as a contemporary operative setting in glioma surgery, although it is not proven so far that ioMRI is crucial to increase resection rates of tumorous tissue [5, 17]. So far, the gold standard to define the extent of resection and to detect tumor borders in MRI is GD-DPTA enhancement [26]. However, leakage of contrast agent and enhancement of reactive tissue might be misleading in $\mathrm{T} 1$ imaging with contrast enhancement [21]. More advanced techniques like T1-weighted dynamic contrast-enhanced MRI or 3D-spectroscopic imaging were recently applied to identify residual tumor in glioblastoma surgery under assistance of intraoperative MRI [27].

In accordance with Coburger et al. and Akbari et al., [1, 28, 29] we believe that a multimodality approach including T2, FLAIR, DTI and spectroscopic imaging as well as dynamic T1-weighted imaging will further improve the sensitivity and specificity of ioMRI and might lead to an improved detection rate and that advanced imaging like dynamic T1-weighed imaging might increase the accura- 

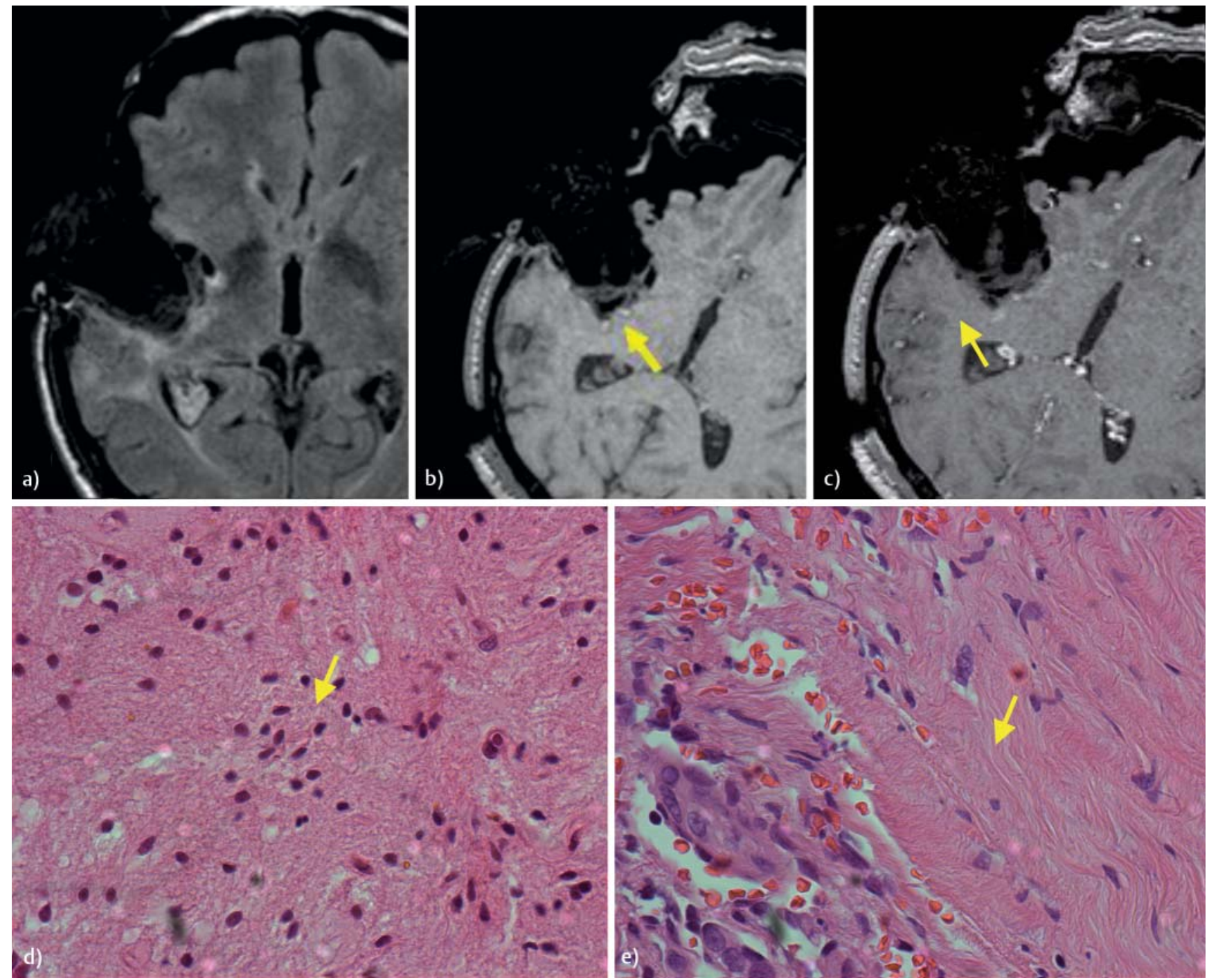

- Fig. 2 ioMRI scan in a 68-year-old male patient with a temporal recurrent glioblastoma: a FLAIR imaging, b T1-SE native scan showing a slightly hyperintense margin at the base of the respective scar (yellow arrow), $\mathbf{c}$ after contrast administration, spotted contrast enhancement of the bottom resection margin and linear enhancement were detectable; $\mathbf{d}$ histopathological specimens after follow-up resection revealed reactive astrogliosis with scattered nuclei surrounded by membranous structures and fibrotic tissue (arrow), but no recurrent glioblastoma was detected in the histopathological workup (d, e, yellow arrow).

- Abb. 2 ioMRI während der Operation eines 68 jährigen Patienten mit einem temporal gelegenen Glioblastomrezidiv: a axiale FLAIR, b T1-SE, Nachweis eines diskret hyperintensen Randsaums am Boden der Resektionshöhle, c nach Kontrastmittelgabe Nachweis von punktförmigen Kontrastmittelanreicherungen und linearen Kontrastmittelanreicherungen am Boden der Resektionshöhle, d reaktive Astrogliose mit gruppierten Nuklei umgeben von mebranösen Strukturen und fibrösem Gewebe (Pfeil), jedoch kein Glioblastomrezidiv in der histopathologischen Aufarbeitung.

cy of ioMRI in the future $[27,29]$. Dynamic contrast enhancement may provide better differentiation between contrast-enhancing tissue and leakage and DTI may reveal additional information about tumor margins [28]. Moreover, operation techniques can be adapted to ioMRI to avoid or reduce leakage of contrast agent [30].

\section{Conclusion}

Intraoperative MRI can sensitively detect residual tumors and can provide optimized control in the resection of high-grade gliomas. Intraoperative MRI can accurately diagnose tumorous contrastenhancing residual tissue using contrast-enhanced T1-weighted imaging after the administration of GD-DPTA. However, false-positive contrast enhancement may occur due to tissue scars and contrast agent leakage in the tumor margin, which may lead to spotted or linear enhancement at the tumor border in T1-weighted imaging after contrast administration. To avoid false-positive 

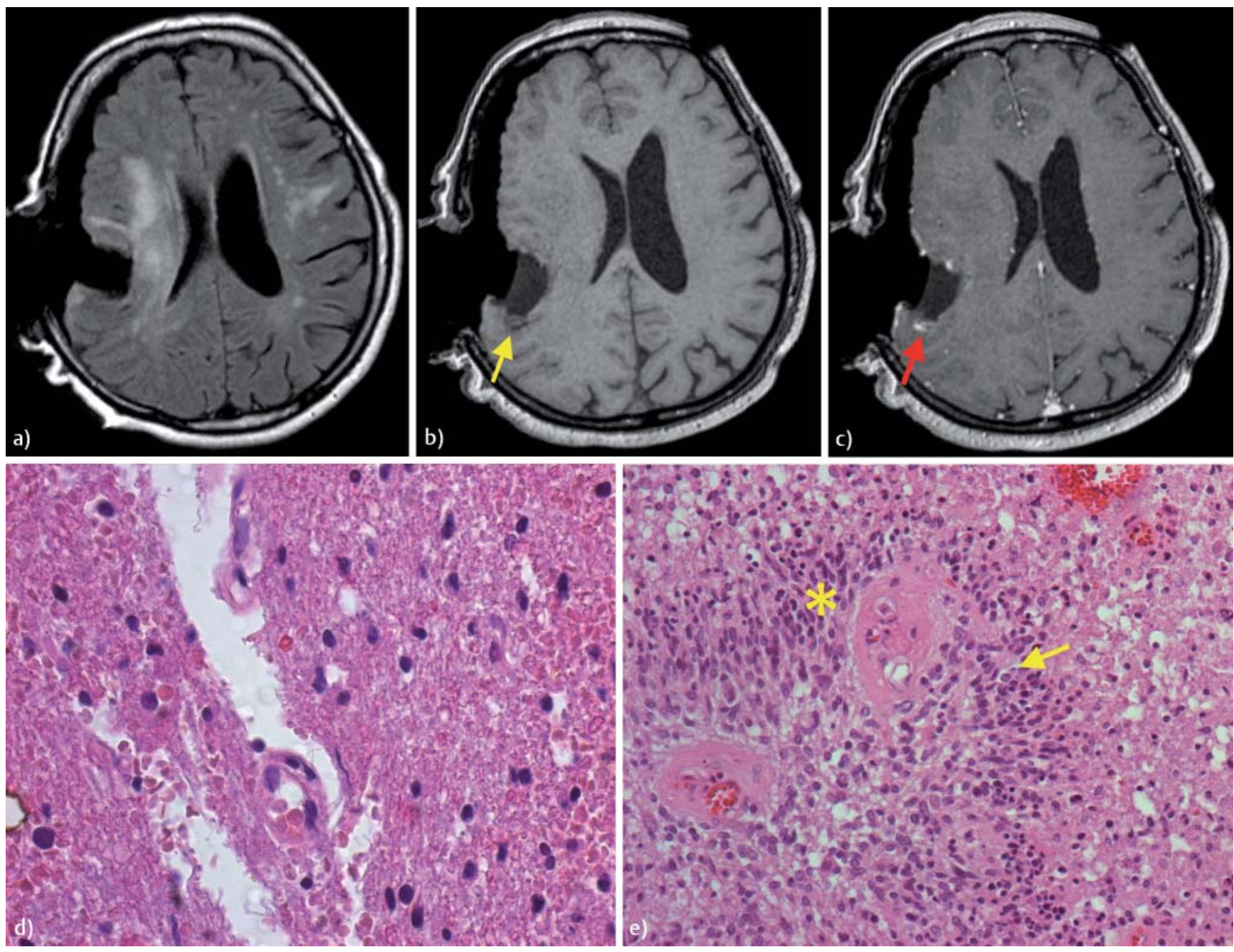

- Fig. 3 ioMRI scan in 58-year-old female with the MRI and histopathological diagnosis of recurrent glioblastoma a transverse FLAIR image presenting slight signal increase at the dorsal resection border, $\mathbf{b}$ native T1 transverse intraoperative MRI with hyperintense signal increase due to methemoglobin adjacent to the resection margin (yellow arrow), c T1-weighted transverse imaging, after contrast administration, additional contrast enhancement is seen (red arrow). $\mathbf{d}$ regular white matter with scattered nuclei and regular shaped vessels is shown, e figure e shows the appearance of glioblastoma with narrowly scattered nuclei, showing different stages of mitosis, irregularly shaped vessels (star) and areas of necrotic tissue (arrow).

- Abb. 3 ioMRI-Untersuchung einer Gliomresektion einer 58 jährigen, weiblichen Patientin mit einem rezidiivierendem Glioblastom. a FLAIR transversal mit geringfügiger Signalanhebung am dorsalen Resektionsrand, b native T1- SE in transversaler Schnittführung mit bandförmiger Signalanhebung (gelber Pfeil), T1-SE nach Kontrastmittelgabe in transversaler Schnittführung, zusätzlicher Nachweis einer Kontrastmittelanreicherung (roter Pfeil), d reguläre weiße Substanz mit irregular verteilten Nuklei und regelrechten Gefäßstrukturen, e Glioblastomnachweis mit eng gruppierten Nuclei mit unterschiedlichen Mitosestadien, irregular konfigurierten Gefäßstrukturen (Stern) and Arealen nekrotischen Gewebes (Pfeil).

results, we recommend exact control of bleeding of the resection margins and application of contrast agent immediately before starting T1-weighted imaging and complementary use of ioMRI and fluorescence guidance.

$\begin{array}{ll}\text { GLOSSARY } & \\ \text { EOR } & \text { extent of resection } \\ \text { GTR } & \text { gross total resection } \\ \text { iOMRI } & \text { intraoperative MRI } \\ \text { FFE } & \text { fast field echo }\end{array}$

\section{FLAIR}

HE-staining

IDH-1

CD31 thrombocyte

EMA

GFAP

ALA fluid attenuated inversion recovery hematoxylin eosin staining isocitrate dehydrogenase 1 endothelial cell adhesion molecule epithelial membrane antigen glial filament acid protein aminolaevulinic acid 


\section{Conflict of Interest}

The authors declare that they have no conflict of interest.

\section{Acknowledgements}

The authors would like to offer their special thanks to Walter Stummer, Department of Neurosurgery, University of Münster for scientific advise and Carsten Liess und Jurgen Bunke, Philips Medical systems, Hamburg, Germany for scientific and technical support.

\section{References}

[1] Coburger ], Engelke J, Scheuerle A et al. Tumor detection with 5-aminolevulinic acid fluorescence and Gd-DTPA-enhanced intraoperative MRI at the border of contrast-enhancing lesions: a prospective study based on histopathological assessment. Neurosurg Focus 2014; 36: E3

[2] Coburger ], Hagel V, Wirtz CR et al. Surgery for Glioblastoma: Impact of the Combined Use of 5-Aminolevulinic Acid and Intraoperative MRI on Extent of Resection and Survival. PLoS One 2015; 10: e0131872

[3] Stummer W, Novotny A, Stepp $\mathrm{H}$ et al. Fluorescence-guided resection of glioblastoma multiforme by using 5 -aminolevulinic acid-induced porphyrins: a prospective study in 52 consecutive patients. Journal of Neurosurgery 2000; 93: 1003-1013

[4] Wirtz CR, Albert FK, Schwaderer M et al. The benefit of neuronavigation for neurosurgery analyzed by its impact on glioblastoma surgery. Neurol Res 2000; 22: $354-360$

[5] Eyupoglu IY, Hore N, Savaskan NE et al. Improving the extent of malignant glioma resection by dual intraoperative visualization approach. PLoS One 2012; 7: e44885

[6] Kreth FW, Berlis A, Spiropoulou V et al. The role of tumor resection in the treatment of glioblastoma multiforme in adults. Cancer 1999; 86: 2117-2123

[7] Schucht P, Beck J, Abu-Isa J et al. Gross total resection rates in contemporary glioblastoma surgery: results of an institutional protocol combining 5-aminolevulinic acid intraoperative fluorescence imaging and brain mapping. Neurosurgery 2012; 71: 927-935; discussion 935-926

[8] Stummer W, Pichlmeier U, Meinel T et al. Fluorescence-guided surgery with 5-aminolevulinic acid for resection of malignant glioma: a randomised controlled multicentre phase III trial. Lancet Oncol 2006; 7: 392 401

[9] Neidert MC, Hostettler IC, Burkhardt JK et al. The influence of intraoperative resection control modalities on survival following gross total resection of glioblastoma. Neurosurg Rev 2016; 39: 401-409

[10] Stummer W, Novotny A, Stepp H et al. Fluorescence-guided resection of glioblastoma multiforme by using 5 -aminolevulinic acid-induced porphyrins: a prospective study in 52 consecutive patients. Journal of neurosurgery 2000; 93: 1003-1013

[11] Roberts DW, Valdes PA, Harris BT et al. Coregistered fluorescence-enhanced tumor resection of malignant glioma: relationships between delta-aminolevulinic acid-induced protoporphyrin IX fluorescence, magnetic resonance imaging enhancement, and neuropathological parameters. Clinical article. Journal of neurosurgery 2011; 114: 595 603

[12] Kubben PL, van Santbrink H. Intraoperative magnetic resonance imaging for high grade glioma resection: Evidence-based or wishful thinking? Surg Neurol Int 2013; 4: 1
[13] Tronnier VM, Wirtz CR, Knauth M et al. Intraoperative diagnostic and interventional magnetic resonance imaging in neurosurgery. Neurosurgery 1997; 40: 891 - 900; discussion 900-892

[14] Steinmeier R, Fahlbusch R, Ganslandt O et al. Intraoperative magnetic resonance imaging with the magnetom open scanner: concepts, neurosurgical indications, and procedures: a preliminary report. Neurosurgery 1998; 43: 739-747; discussion 747-738

[15] Martin AJ, Hall WA, Liu H et al. Brain tumor resection: intraoperative monitoring with high-field-strength MR imaging-initial results. Radiology $2000 ; 215: 221-228$

[16] Senft C, Bink A, Franz K et al. Intraoperative MRI guidance and extent of resection in glioma surgery: a randomised, controlled trial. Lancet Oncol 2011; 12: $997-1003$

[17] Gessler F, Forster MT, Duetzmann S et al. Combination of Intraoperative Magnetic Resonance Imaging and Intraoperative Fluorescence to Enhance the Resection of Contrast Enhancing Gliomas. Neurosurgery 2015; 77: 16 -22; discussion 22

[18] Coburger J, Scheuerle A, Kapapa T et al. Sensitivity and specificity of linear array intraoperative ultrasound in glioblastoma surgery: a comparative study with high field intraoperative MRI and conventional sector array ultrasound. Neurosurg Rev 2015; 38: 499-509; discussion 509

[19] Liang D, Schulder M. The role of intraoperative magnetic resonance imaging in glioma surgery. Surg Neurol Int 2012; 3: S320 - S327

[20] Kubben PL, Scholtes F, Schijns OE et al. Intraoperative magnetic resonance imaging versus standard neuronavigation for the neurosurgical treatment of glioblastoma: A randomized controlled trial. Surg Neurol Int 2014; 5: 70

[21] Stummer W. Commentary: Combining 5-Aminolevulinic Acid Fluorescence and Intraoperative Magnetic Resonance Imaging in Glioblastoma Surgery: A Histology-Based Evaluation. Neurosurgery 2016; 78: 484486

[22] Lacroix M, Abi-Said D, Fourney DR et al. A multivariate analysis of 416 patients with glioblastoma multiforme: prognosis, extent of resection, and survival. J Neurosurg 2001; 95: 190-198

[23] Albert FK, Forsting M, Sartor $\mathrm{K}$ et al. Early postoperative magnetic resonance imaging after resection of malignant glioma: objective evaluation of residual tumor and its influence on regrowth and prognosis. Neurosurgery 1994; 34: 45 - 60; discussion 60-41

[24] Mager AK, Theisgen H, Götz C et al. Treffsicherheit der intraoperativen MR-Bildgebung in der Nachweisbarkeit von Resttumorgewebe zur Resektion hochgradiger (Grad IV) Gliome. Clinical neuroradiology 2014; 24 (Suppl. 1): 1-106

[25] Stummer W, Stepp H, Moller G et al. Technical principles for protoporphyrin-IX-fluorescence guided microsurgical resection of malignant glioma tissue. Acta Neurochir (Wien) 1998; 140: 995-1000

[26] van den Bent MJ, Wefel JS, Schiff D et al. Response assessment in neurooncology (a report of the RANO group): assessment of outcome in trials of diffuse low-grade gliomas. Lancet Oncol 2011; 12: 583-593

[27] Ozduman K, Yildiz E, Dincer A et al. Using intraoperative dynamic contrast-enhanced T1-weighted MRI to identify residual tumor in glioblastoma surgery. Journal of neurosurgery 2014; 120: 60 -66

[28] Engelhorn T, Schwarz MA, Hess A et al. Definition of K(trans) and FA thresholds for better assessment of experimental glioma using highfield MRI: a feasibility study. Clinical neuroradiology 2014; 24: 337-345

[29] Akbari H, Macyszyn L, Da X et al. Imaging Surrogates of Infiltration Obtained Via Multiparametric Imaging Pattern Analysis Predict Subsequent Location of Recurrence of Glioblastoma. Neurosurgery 2016; 78 : $572-580$

[30] Heckl S, Feigl GC, Honegger ] et al. [Intraoperative MRI (iMRI) in neurosurgery: a radiological point of view]. Rofo 2012; 184: 1-5 